\title{
Rural Tourism Contributions to Rural Development in the Eastern Black Sea Region of Turkey
}

\author{
Ismet Boz ${ }^{1}$, Osman Kilic ${ }^{2}$, Cevahir Kaynakci ${ }^{3}$ \\ ${ }^{1,2,3}$ Ondokuz Mayıs University, Department of Agricultural Economics,College of Agriculture, Samsun \\ 55139 Turkey
}

\begin{abstract}
Rural tourism is considered as one of the essential elements making significant contributions to rural development in many developing countries. A well planned and adequately operated rural tourism sector provides job opportunities for local people, increases living standards, alleviates poverty, prevents migration, and ultimately makes it possible for rural people to enjoy living at their original places of residencies. All of these benefits encourage governments and all other relevant stakeholders to put more emphasis on rural tourism activities when planning and to implement rural development programs. The primary aim of this study was to examine the opportunities of sustainable rural tourism in the Eastern Black Sea Region of Turkey. It based on an extensive review of related literature, governmental reports, and experiences and observations of the researchers in the region. The study revealed that the Eastern Black Sea region has a remarkable rural tourism potential and it will make significant contributions to rural development in Turkey. Particularly highlands, thermal hotels, rural activities, farms, and agribusiness are increasingly attracting many domestic and international tourists in every passing year. However, environmental dimension of rural tourism is under risk because of unplanned housing and road constructions which put more pressure on agricultural lands and rural landscape. For this reason, it is important to consider economic, social, and environmental dimensions of sustainability when preparing and implementing rural tourism programs for the region
\end{abstract}

Keywords: Rural development, Rural tourism, Agri-tourism, Sustainable development, Sustainability.

\section{Introduction}

Development, in general, is defined as to regulate a nation's economy to expose improvements in desirable ways. More broadly it is defined as any kinds of desired changes and improvements in economic, social, and political situations of a country [1]. Rural areas and agricultural sector play an important role in economic development, particularly in developing countries. They support economic development by providing employment opportunities for a particular portion of the population living in rural areas, necessary nutrition materials for rural and urban communities, and raw materials for agri-food industry. The agricultural sector also makes contributions to national income, exports, and input manufacturing industry [2]. Rural development is defined as studies to eliminate all adverse environmental conditions influencing human life in rural areas [3]. According to another definition, rural development is the process of combining the effort of rural communities with the governmental effort to improve economic, social and cultural conditions in rural areas. It is also the process of integrating rural communities with the rest of the population and providing their full involvement in developmental efforts throughout a country [4]. However, in many developing countries the people living in the countryside are spread over a large area as compared to urban settlements, development programs for rurality are more challenging to implement. Governments can develop various plans to minimize the development differences between rural and urban areas within the framework of economic, social, and environmental legislation. Rural tourism can be considered as one of these policies which can eliminate the developmental gaps between urban areas and the countryside.

Rural tourism is considered as a sub-category of alternative tourism. A sustainable rural tourism sector can be easily integrated with other types of tourism as it is consistent with rural culture, natural environment, and agricultural life. Therefore, rural tourism, enriched with various local, national and international initiatives, attracts people to the 
countryside for vacation [5]. Another definition states that rural tourism is mostly a type of farming and nature-oriented tourists participating in activities such as farming, fishing, horse riding, trekking, etc. [6]. According to the World Tourism Organization (WTO), rural tourism is composed of four main elements in which rural communities are located in the center. These are (1) rural areas, (2) rural heritage and culture, (3) rural activities and (4) rural life [7] The characteristics of rural tourism are listed as the following [8]:

(1) Activities are carried out in rural areas.

(2) It is functionally operated with small-scale enterprises which have interactions with nature, cultural heritage, traditional society, and traditional practices.

(3) The buildings and residential areas are small scale and represent rurality.

(4) It shows a traditional character. Growth is natural and slow. It is linked to rural families. It should be tightly controlled locally and developed for the benefit of the rural community in the long run.

(5) Contains a structure that incorporates the concepts of rural environment, rural economy, rural history, and rural settlement.

Sustainable rural tourism should primarily cover tourism activities that do not allow the above features to deteriorate. In this context, by using the economic opportunities of the rural areas, it increases the quality of life of the people living there, protects the natural environment and ensures that the tourists visiting the rural areas have a good time here. According to the reviewed literature, to be sustainable, rural tourism must be carried out considering three main dimensions which are (1) economic (2) sociocultural and (3) and environmental dimension [9], [10]. These are described as follows:

Economic dimension: Small-scale accommodation facilities and commercial establishments should be able to provide tourists with high-level satisfaction from their visits. The local people mostly establish these enterprises, and the personnel they employ are also selected from the locality. With this dimension, rural tourism contributes to the economy by increasing the attractiveness and creating employment opportunities. Besides, tourists who visit rural areas purchase agricultural products and village handicrafts. In this respect, rural tourism supports economic development by contributing to the generation of demand for the products produced locally.

Socio-cultural dimension: Social and cultural coexistences between rural and urban people are increasing with the development of rural tourism. First of all, information exchange is possible when people living in urban areas arrange visits to the countryside. Both sides become familiar with their lifestyles, traditions, and cultures [11]. On the other hand, international visitors increase the tolerance of rural people towards different customs and traditions [12]. Moreover, there has been an uncontrolled domestic migration from the countryside to urban areas [13]. Rural tourism increases new job opportunities in rural areas and decreases the migration from villages to cities, and therefore the problems of unplanned urbanization and housing in big cities can be solved [14].

Environmental dimension: While trying to increase the contributions that rural tourism makes to the rural economy, governments may face difficulties in protecting natural resources and the environment, mainly if the demand for visitors is exceptionally high. In this case, if short-term profitability is kept in the foreground, in the areas, where small-scale rural tourism is possible with the present conditions, will probably be disappeared in the long run. The pressure to develop rural tourism intensively has led to the transformation of this business into mass tourism and has led to the establishment of new parks, conference centers, holiday villages and recreational areas in the countryside. The insatiable desires of mankind to utterly capitalize on the natural features of rural areas with capitalist thinking, over time, cause these areas to deteriorate and face significant environmental problems.

Research conducted in rural tourism activities showed that small-scale tourism businessmen in the countryside are quite satisfied with the visitors as they are highly interested in their business, homemade food items, handicrafts, and their way of living in rurality. On the other hand, they expect more public services such as better roads for transportation, regular garbage collection by the municipalities, and other related social services [15]. The primary purpose of this study was to examine the present situation of rural tourism in the Eastern Black Sea Region of Turkey. The specific objectives were to specify rural tourism concept within the general concept of tourism, identify rural tourism destinations in the region, summarize the indicators of sustainable tourism for the region, examine future trends and opportunities, and develop recommendations for sustainable rural tourism in the region.

\section{Materials and Methods}

Since this study was intended to be carried out as qualitative research, the primary material used was 
information provided by a review of the related literature and experiences and observations of the researchers in the region. In this sense journal articles, books, institutional reports, and the Internet were extensively utilized. The paper was organized considering the primary purpose and specific objectives of the study. Therefore, the concept of rural tourism, its importance in rural development, its fundamental elements, characteristics, and dimensions was explained in the introduction section. Then a general description of the Black Sea Region, rural tourism destinations and opportunities in the region, and sustainable tourism indicators for the area were examined. The study concludes with a set of recommendations for developing a long-term sustainable rural tourism sector for the region.

\section{Research Findings}

The Black Sea Region is on the northern border of Turkey. It includes three parts, namely, the eastern, the central, and the western black sea regions. This region stretches along the Black Sea from the west side of Turkey's northern border. The area continues from the east of the Sakarya province to the edge of Georgia. On the shores of the Black Sea region, the mountains extend parallel to the sea. Because of this, moisture cannot go to the inner zone, so there is a lot of rainfall. Due to over-precipitation, the region is often covered with forests, and there is a lot of greenery. As there are many rivers and lakes, streaming tourism is developed and widely used. It is stunning as compared to other regions because it is abundant in mountains, highlands, forests, pastures, rivers, national parks, and individual farms, growing mostly tea and hazelnuts. For this reason, nature tourism has remarkable potential, and all of these destinations need to be seen and visited. There are also many historical beauties in the Black Sea region. For example, the Monastery of Sumela is famous as the place where the graves of the kings are located. The rivers are very convenient for sports such as rafting which has become very popular in the river Coruh. Historical monuments in Trabzon (Sumela Monastery) and Amasya (King's graves) constitute essential tourism potentials of the region.

Rural tourism efforts in the region will consider the major components of the natural beauties, historical sites, socioeconomic characteristics, and cultural heritage of the area.

\subsection{Rural tourism opportunities in the Eastern Black Sea Region}

Tourism establishments in the Eastern Black Sea Region are presented in Table 1. Trabzon is the most developed and attractive city in the region as the numbers of establishments, rooms, and beds are quite higher than other cities. The provincial and district municipalities in the region also have many establishments which aren't included in this table. Trabzon is a metropolitan city with an international airport, harbor, universities, and many historical and natural places. In addition to two states and one private university in Trabzon, every other city in the region has also a state university. The second international airport in the region constructed two years ago between the provinces of Ordu and Giresun. Another one is being built on the coastal area of Rize. Since the region is expected to attract domestic and international tourists in increasing numbers in the future, more establishments and facilities will be needed in each province and even in each district.

The number of domestic and international tourists visiting the region is increasing from year to year. As it can be followed from Table 2, in 2015 the number of tourists checked in the tourism establishments exceeded 1.6 million. In addition to the natural beauties it has, the availability of cultural, historical and local components, and the sincerity of the local people will make this region more attractive for tourists in the future. The region welcomes millions of local and foreign tourists, especially for the tourists coming from the Gulf countries, it has become a shining star of tourism by reaching a capacity of 7 thousand beds (including the municipality establishments) with 4-5-star hotel investments made in the last few years.

The Eastern Black Sea region has many rural tourism destinations which are presented in Table 3. Different themes, such as winter tourism, plateau tourism, beaches, and thermal tourism are possible. In terms of conventional tourism, the region isn't as attractive as the southern and western coastal cities of Turkey, but in terms of plateaus and mountains, it has quite more advantages than those cities of other regions. Therefore, for the future development plans and policies, more emphasis must be placed on countryside tourism for this region.

\subsection{Sustainability indicators for the tourism sector in the region}

To evaluate rural tourism opportunities for a region in a long-term span, various sustainable indicators were developed by different organizations around the world. The World Tourism Organization 
Table 1. Number of tourism establishments in the Eastern Black Sea Region

\begin{tabular}{|c|c|c|c|c|c|c|}
\hline \multirow{2}{*}{ City } & \multicolumn{2}{|c|}{ Tourism Investment Licensed } & \multicolumn{2}{c|}{ Tourism Operation Licensed } \\
\cline { 2 - 6 } & $\begin{array}{c}\text { Number of } \\
\text { Establishment } \\
\text { s }\end{array}$ & $\begin{array}{c}\text { Number } \\
\text { of Rooms }\end{array}$ & $\begin{array}{c}\text { Number } \\
\text { of Beds }\end{array}$ & $\begin{array}{c}\text { Number of } \\
\text { establishments }\end{array}$ & $\begin{array}{c}\text { Number } \\
\text { of Rooms }\end{array}$ & $\begin{array}{c}\text { Number } \\
\text { of Beds }\end{array}$ \\
\hline Trabzon & 18 & 1207 & 2467 & 38 & 2189 & 4476 \\
\hline Ordu & 8 & 514 & 1004 & 27 & 1162 & 2331 \\
\hline Giresun & 9 & 362 & 760 & 17 & 560 & 1091 \\
\hline Rize & 7 & 448 & 910 & 13 & 531 & 1064 \\
\hline Artvin & 4 & 103 & 206 & 9 & 515 & 1021 \\
\hline Gumushane & 2 & 145 & 301 & 5 & 159 & 306 \\
\hline Total & 48 & 2779 & 5649 & 60 & 5116 & 10289 \\
\hline
\end{tabular}

Source: Cokisler and Turker, 2015 [16].

Table 2. Number of tourists visited the Eastern Black Sea Region

\begin{tabular}{|l|l|l|l|l|l|l|}
\hline \multirow{2}{*}{ Places Stayed } & \multicolumn{5}{|l|}{ Entered Establishment } & \multicolumn{2}{l|}{ Spent Night } \\
\cline { 2 - 7 } & Foreign & Domestic & Total & Foreign & Domestic & Total \\
\hline Hotels & 116,042 & 889,73 & $1,005,115$ & 215,130 & $1,147,574$ & $1,362,704$ \\
\hline Motels & 2,899 & 29,467 & 32,366 & 12,105 & 38,135 & 50,240 \\
\hline Pensions & 11,456 & 117,461 & 128,917 & 15,985 & 179,520 & 195,505 \\
\hline $\begin{array}{c}\text { Holiday } \\
\text { village }\end{array}$ & 6,171 & 6,171 & & 6,171 & 6,171 \\
\hline Camping & 936 & 20,728 & 21,664 & 1,202 & 20,958 & 22,160 \\
\hline TOTAL & 131,333 & $1,062,90$ & $1,194,233$ & 244,422 & $1,392,358$ & $1,636,780$ \\
\hline
\end{tabular}

Source: DOKAP Eylem Plani 2014-2018 [17].

(WTO) determined 140 sustainable tourism indicators which can be used to measure the sustainability of different destinations. After the indicators are selected for some specific destinations, they can be maintained so that comparisons between the destinations can be made. For the Black Sea region, four dimensions of sustainable tourism such as economic, social, environmental, and physical planning and control were determined in advance. Then seven indicators under economic dimension, nine indicators under social dimension, seven indicators under environmental dimension, and two indicators under physical planning and control dimension were selected from the WTO's list. A sustainable tourism performance index was developed considering all of these indicators. The sustainable tourism indicators for the Black Sea region include the following [18]:

Economic Indicators: Improvements in the number of days spent; transportation by airway and railroads; accommodation diversity; tourism investments; quality of indicators predicting economic efficiency; producing local tourism services; and management of available tourism facilities by local actors.

Social Indicators: Women employment; social effects of tourism on employment; education level of employees in tourism businesses; information on local culture and protecting cultural heritage; the nature, variety, and numbers of cultural settings; net migration rate; general status of contemporary, traditional, and monumental heritage; tourism services provided for disabled; and general status of health services.

Environmental Indicators: Gathering, reusing, and recycling of solid wastes; emission level and pollutants of the atmosphere; sustainable management of reforestation and erosion control work; ecosystem sensitivity; capacity and usability of renewable energy reserves and networks; quality of drinkable water; and natural resource use in tourism areas.

Physical Planning and Control Indicators: Efficiency in planning, control and management systems and institutional consultancy and communication effort.

\section{Conclusions and Recommendations}

The recent developments in the rural tourism sector of the Eastern Black Sea Region imply that this sector will make significant contributions to local people and Turkey at large. However, longterm plans and programs must be developed considering the impact of these indicator. Otherwise, excessive and intensive use of rural areas can disrupt 
ecological balance by destroying agricultural, natural and cultural sites. This may end up with changes in agricultural production patterns, and diminishes in yield and productivity. Reduced productivity in agriculture can accelerate rural tourism, which is one of the alternative income sources in the beginning.

Table 3. Tourism destinations in the Eastern Black Sea Region

\begin{tabular}{|c|c|c|c|c|}
\hline Name of the Destination & Province & District & Theme & $\begin{array}{l}\text { Area (Kilometer } \\
\text { square) }\end{array}$ \\
\hline $\begin{array}{l}\text { Artvin Kackar Tourism Center } \\
\text { (TC) }\end{array}$ & $\begin{array}{l}\text { Artvin Rize } \\
\text { Erzurum }\end{array}$ & $\begin{array}{l}\text { Yusufeli } \\
\text { Camlihemsin Ispir }\end{array}$ & Winter & 19,549 \\
\hline Artvin Kafkasor & Artvin & Artvin & Winter & 1,652 \\
\hline Bayburt Kop Mountain TC & Bayburt & Bayburt & Winter & 4,170 \\
\hline Giresun Aksu TC & Giresun & Giresun & Beach & 9 \\
\hline Giresun Kumbet Plateau TC & Giresun & Dereli & Plateau & 825 \\
\hline $\begin{array}{l}\text { Giresun Yavuzkemal Plateau } \\
\text { TC }\end{array}$ & Giresun & Giresun, Dereli & Plateau & 610 \\
\hline $\begin{array}{l}\text { Gumushane Cakirgol Winter } \\
\text { Sports TC }\end{array}$ & Gumushane & Gumushane & Winter & 6,000 \\
\hline $\begin{array}{l}\text { Gumushane } \\
\text { Winter Sports TC }\end{array}$ & Gumushane & Gumushane & Winter & 794 \\
\hline Gumushane Zigana TC & Gumushane & Torul & Winter & 301 \\
\hline Ordu Akkus Argin Plateau TC & Ordu & Akkus & Plateau & 220 \\
\hline $\begin{array}{l}\text { Ordu Aybasti Persembe Plateau } \\
\text { TC }\end{array}$ & Ordu & Aybasti & Plateau & 975 \\
\hline $\begin{array}{lll}\text { Ordu } & \text { Aybasti } & \text { Toygar } \\
\text { Kabaktepe TC } & & \\
\end{array}$ & Ordu & Aybasti & Plateau & 60 \\
\hline Ordu Bolaman TC & Ordu & Ordu & Beach & 4,250 \\
\hline Ordu Cambasi Plateau TC & Ordu & Kabaduz & $\begin{array}{l}\text { Plateau, } \\
\text { Winter }\end{array}$ & 320 \\
\hline $\begin{array}{lll}\text { Ordu } & \text { Mesudiye } & \text { Keyfalan } \\
\text { Plateau } & & \\
\end{array}$ & Ordu & Mesudiye & Plateau & 730 \\
\hline $\begin{array}{ll}\text { Ordu Mesudiye } & \text { Yesilce- } \\
\text { Topcam Plateaus } & \end{array}$ & Ordu & Mesudiye & Plateau & 17,000 \\
\hline Ordu-Fatsa-Cerkezler & Ordu & Fatsa & Beach & 23 \\
\hline Rize Anzer TC & Rize & İkizdere & Plateau & 5,600 \\
\hline $\begin{array}{l}\text { Rize Camlihemsin } \quad \text { Ayder } \\
\text { Thermal TC }\end{array}$ & Rize & Camlihemsin & $\begin{array}{l}\text { Plateau, } \\
\text { Winter, } \\
\text { Thermal }\end{array}$ & 550 \\
\hline Rize Cayeli TC & Rize & Cayeli & Beach & 465 \\
\hline $\begin{array}{l}\text { Rize İkizdere Ovit Mountain } \\
\text { Winter Sports TC }\end{array}$ & Rize & Ikizdere & Winter & 5,123 \\
\hline $\begin{array}{lll}\text { Trabzon } & \text { Arakli } & \text { Pazarcik } \\
\text { Plateau TC } & & \\
\end{array}$ & Trabzon & Arakli & Plateau & 320 \\
\hline Trabzon Arakli TC & Trabzon & Arakli & Beach & 190 \\
\hline $\begin{array}{lrr}\text { Trabzon Arakli } & \text { Yesilyurt } \\
\text { Yilanta Plateau TC } & \end{array}$ & Trabzon & $\begin{array}{l}\text { Arakli, Surmene, } \\
\text { Dernekpazari }\end{array}$ & Plateau & 27,600 \\
\hline $\begin{array}{l}\text { Trabzon Giresun Sis Mountain } \\
\text { TC }\end{array}$ & Trabzon & Salpazari & Plateau & 379 \\
\hline Trabzon Macka Solma TC & Trabzon & Macka & Plateau & 230 \\
\hline $\begin{array}{l}\text { Trabzon Tonya Armutlu, } \\
\text { Gumushane Kurtun Erikbeli }\end{array}$ & $\begin{array}{l}\text { Trabzon, } \\
\text { Gumushane }\end{array}$ & Tonya, Kurtun & Plateau & 1,178 \\
\hline
\end{tabular}

Source: DOKAP Eylem Plani 2014-2018. [17]. 
However, not planning rural tourism in a sustainable way in the beginning period may cause serious environmental problems and begin to destruct the potential of rural tourism.

The environmental dimension of rural tourism in the region is closely related to sustainable farming activities. Sustainability in farming sector requires farmers who have more frequent contact with extension services, higher education, ownership of land, and greater access to information [19]. These characteristics can be improved throughout longterm promoted agri-environmental programs which in Turkey significantly influenced the protection of land and other natural resources [20], [21]. For this reasons, particularly tea and hazelnut farmers in the coastal areas, and animal husbandry in the inner and higher altitudes must be sustained to support rural tourism activities regarding agri-tourism. Many visitors from Europe and other continents are highly interested in the lifestyle of peasants living in the locality. They really want to spend some time with peasants and learn their lifestyles and customs. They are also willing to pay for accommodations. However, villagers aren't familiar with this kind of quests and activities. Therefore, the government must develop a program to bring together the tourists and the hosts.

Above all, successful planning, management, monitoring and evaluation of the rural tourism sector is very important for sustainable economic, socio-cultural and environmental aspects of the country's economy. It cannot be said that rural tourism in the Eastern Black Sea Region has sufficient infrastructure. The sector generally consists of small businesses with sustainable income at risk. Therefore, implementation, monitoring, and evaluation of various projects considering all of the dimensions of this sector is essential.

\section{References}

[1] Ş.Tüylüoğlu, H. Çeştepe, "Kalkınma Teorilerinin Temelleri ve Gelişimi." Kalkınma Ekonomisi: Seçme Konular, Ed: Sami TabanMuhsin Kar, Ekin Kitabevi Yayınları, Bursa, p:27-69, 2004.

[2] İ. Boz, “Tarım Sektörünün İktisadi Kalkınmadaki Rolü.” Kalkınma Ekonomisi: Seçme Konular, Ed: Sami Taban-Muhsin Kar, Ekin Kitabevi Yayınları, Bursa, p: 137-158. 2004.

[3] A. Tolunay, A. Akyol, "Kalkınma ve kırsal kalkınma: Temel kavramlar ve tanımlar." Süleyman Demirel Üniversitesi Orman
Fakültesi Dergisi Seri: A, v. 2, p. 116- 127, 2009.

[4] N. Kuşat, "Sürdürülebilir kırsal kalkınma için bir alternatif olarak kırsal turizm ve Türkiye'de uygulanabilirliği." AİBÜ-İ̈BF Ekonomik ve Sosyal Araştırmalar Dergisi. v. 10, p. 65-87, 2014.

[5] F. Soykan, "Dogal cevre ve kirsal kulturle butunlesen bir turizm turu: Kirsal turizm." Anatolia Turizm Arastirmalari Dergisi (Türkçe). Yil: 10, Mart-Haziran, p. 67-75, 1999.

[6] S. Yarcan, "Türkiye'de Turizm ve Uluslararasılaşma.” Boğazici Universitesi Yayini, Istanbul. 1998.

[7] World Tourism Organization (WTO). Rural tourism in Europe: Experiences, development, and perspectives. Belgrade (Serbia and Montenegro), 24 and 25 June 2002: Kielce (Poland), 6 and 7 June 2003; Yaremcha (Ukraine), 25 and 26 September 2003.

[8] B. Lane, "Sustainable rural tourism strategies: A tool for development and conservation." Journal of Sustainable Tourism. v. 2, p. 102111, 1994.

[9] T. Rifai, "Tourism and rural development: the sustainability challenge." Rural 21 , v. 45 , p. 810, 2011.

[10] I. V. Dragulanescu, M. Drutu (Ivan), "Rural tourism for local economic development." International Journal of Academic Research in Accounting, Finance, and Management Sciences. v. 2, p. 196-203, 2012.

[11]K. Esengün, H. Akça, M. Sayili, "Kırsal alanların kalkındırılmasında kırsal turizmin rolü." Tarım Kredi Kooperatifleri Merkez Birligi Yayını. Ekin Dergisi v. 11, p. 81-91, 2001.

[12] S. Sertkaya, "Bartın İli Kıyı Bölgesinin Turizm ve Rekreasyon Potansiyelinin Saptanmas1 ve Değerlendirilmesi Üzerine Bir Arastırma." Ankara Universitesi Fen Bilimleri Enstitüsü Peyzaj Mimarisi Anabilim Dali Doktora Tezi (Basilmamis). Ankara, 2001.

[13] M. Aslan, İ. Boz, "Kırsal alandan kentlere göçü etkileyen faktörler: Adana örneği." Türkiye VI. Tarım Ekonomisi Kongresi, Tokat. 2004

[14] M. Uçar, H. Uçar, A. Kurnaz, H. Kurnaz, "Kursal turizmin sosyo-ekonomik yapiya etkisi ve Fethiye Örneği." Karamanoğlu Mehmetbey Universitesi Sosyal Ve Ekonomik Arastirmalar Dergisi. v. 1, p. 75-82, 2012.

[15]B. Demir, İ. Boz, "Bursa İli Yıldırım İlçesi Cumalıkızık Köyünde kırsal turizm 
çalışmalarının kırsal kalkınma açısından değerlendirilmesi." Tarım Bilimleri Araştırma Dergisi. v.10, p. 50-55, 2017

[16] N. Cokisler, A. Turker, "Dogu Karadeniz Bolgesinin yerli turist profili ve pazar bolumlendirmede kullanimi." Karadeniz Arastirmalari, v. 44, p. 33-57.2015.

[17]DOKAP. Dogu Karadeniz Projesi (DOKAP) Eylem Plani (2014-2019). T.C. Kalkinma Bakanligi Dogu Karadeniz Bolgesi Bolge Kalkinma Idaresi. 2017. Accessed May 9, 2017 from:http://dokap.gov.tr/wpcontent/uploads/2016/12/DOKAP-EylemPlan\%C4\%B1-2014-2018.pdf

[18] I. Calik, O. Batman, "Dogu Karadeniz Bolgesi surdurulebilir turizm gostergeleri arastirmasi (Eastern Black Sea Region sustainable tourism indicator research). Dogu Karadeniz Bolgesi Surdurulebilir Turizm Kongresi. 14-16 Mayis Bildiri Kitabi. Gumushane Universitesi Turizm Fakultesi. 2014.

[19]F. F. Tatlidil, İ. Boz, H. Tatlidil, "Farmers' perception of sustainable agriculture and its determinants: a case study in Kahramanmaras province of Turkey." Environment, Development, and Sustainability, v. 11, n. 6, p.1091-1106, 2009.

[20] I. Boz, "Effects of environmentally friendly agricultural land protection programs: Evidence from the Lake Seyfe area of Turkey." Journal of Integrative Agriculture. v. 15(8), p. 19031914, 2016.

[21] I. Boz, 'Determinants of farmers' enrollment in voluntary environmental programs: evidence from the Eregli Reed Bed area of Turkey." Environment, Development, and Sustainability, 1-19.(Online First Issue) 